\title{
Can Food Crop Medicine Reduce Pressure on Forest Harvest in Nigeria?
}

\author{
Gbadebo Jonathan Osemeobo \\ Department of Biological Sciences, \\ Bells University of Technology, \\ P. M .B. 1015, Ota, Ogun State, Nigeria.
}

Email: osemeobo@yahoo.com

\begin{abstract}
Awareness created in the social media through smart phones had popularized the practice of using food crop parts such as leaves, fruits, roots and seeds to treat common illness which had hitherto been treated with herbs from the wild. This study investigated whether the use of food crops for medicine can reduce pressures of harvesting medicinal plants from the forest. A combination of three research methods: structured questionnaire survey; informal discussions with stakeholders in food crop medicines and observations on collection and preparation of food crop medicines were used to collect data. Simple random sampling method was used to select 62 respondents for questionnaire survey and discussion groups in Ota Ogun State, Nigeria. Data were presented in tables and percentages. A Chi-square analysis was used to test the research hypothesis. Results derived from data analyses indicated that food crop medicine (FCM) was: (i) widely used; (ii) fully accepted; (iii) gradually reducing pressures in natural forests; and (iv) used to compliment indigenous traditional medicine. A conclusion was reached that FCM had come to stay as a major primary health delivery. Moreover, FCM has found a place in herbal treatments of diseases.
\end{abstract}

Keywords: Food crop medicine, Traditional medicine, Traditional plants, Natural forests, Herbs.

\section{INTRODUCTION}

Globally, medicinal plants are being lost at very high speed (Osemeobo, (2010a) . The threats are spreading as wide fire through habitat destruction, overharvesting and bioprospecting. The threats are aggravated because habitat loss is strongly tied onto high valued chain (Peter, 2020). Overharvesting of wild plants used for traditional medicine (TM) had led to extinction of species (Suellen et. al., 2020). Nevertheless, traditional medicine was developed for centuries to meet indigenous requirements for treatments of diseases in Nigeria and other parts of the world (Fatemech et al, 2018). It had been said that from ancient times to the present day; $80 \%$ of world's people from Europe through America to Africa depend on traditional medicine for primary health care needs (WHO, 2019 and Peter, 2020). According to Oladeji (2016), two-third of the world's population depends on herbal medicine for primary health care because of their better cultural acceptability, compatibility and adaptability with the human body with low recorded side effects. Nigeria records one of the worst cases of biodiversity loss through medicinal harvest in Africa (Osemeobo, 2018). Nigerian forests are being devastated as a result of combined efforts of increasing high rates 
of poverty, increasing deforestation for agriculture and expanding urbanization which had led to a near total collapse of forest protection. Many studies (Pandey and Sativa 2012); and Hindan et al., 2020) have suggested how to reduce loss of species resulting from impacts of forest harvest for traditional medicine. These suggestions which pointed to in situ conservation failed to work in the country. However, the bone of contention in Nigeria revolves around the facts that reserved forests are no longer protected as they were three to four decades ago (Osemeobo, 2011) .

Most rural Nigerian women living in settlements close to forests have developed a trade chain with urban women in medicinal plant trade. According to Ezekwesili-Ofili et al. (2019), medicinal plant collectors apply five destructive methods in collecting medicinal plants transported for use in urban areas. These include: uprooting seedlings in whole plant utilization; de-barking trees of choice; harvesting apical leaves of plants; harvesting mature and immature fruits (which deprive natural regeneration (Osemeobo, 2005a); and pruning crowns of trees. Lack of law enforcement on forest harvest for traditional medicine led to extirpation of 22 species of medicinal plants in the rain forest zone of Nigeria (Osemeobo, 2005b). Again, Osemeobo (2011) also reported that an average exploiter of medicinal plants in the Nigerian rainforest harvested $62 \mathrm{~m}^{3}$ of woody products, $337 \mathrm{~kg}$ for leafy medicine which yielded an income of between N1.7 million (USD 11,957) and N 910,352 (USD 36, 743) per annum (Osemeobo, 2005b).

Loss of forests translates to risks of weakening indigenous ecological knowledge, loss of common property rights and vulnerability of those that depend on the forests for livelihoods (Osemeobo, 2005b; and Osemeobo, 2010a). Researchers have conceptualized frameworks of mediation between forest exploiters and those whose livelihoods are tied to the forests (Fatemech et al., 2018; and Osemeobo, 2018). Unfortunately, such mediation policy could not be applied to Nigerian forests due to a total breakdown of forest protection and conservation activities in government owned forest reserves. Illegal activities have overpowered attempts for forest conservation; hence reliance on forest harvest for traditional medicine for everyday use remains a forlorn hope. Major medicinal plant species of choice are either extirpated or lost (Osemeobo, 2018). This has continuously discouraged women who live on forest herbs to sustain their families (Osemeobo, 2005b). It was becoming difficult for traditional health care practitioners to source for medicinal herbs in natural forests thereby making traditional health care delivery unsustainable. The concept of FCM stems from traditional believes that edible food crop parts have therapeutic agents for treatment of diseases. The FCM is accepted and adopted in major towns in the country; and is gradually replacing some aspects of traditional medicine. Their preparations have strongly appealed to moral sensibilities that their uses are safe because they are from the food people eat. This study is anchored on the hypothesis that FCM is not reducing pressures on harvesting medicinal plants from natural forests. The study objective was therefore to investigate whether FCM is reducing pressures of forest harvest for medicinal plants. The following research questions were addressed in this study: are FCM accepted by people? Are FCM effective in health care delivery? Do people patronize traditional medicine as before?

\section{MATERIALS AND METHODS}

Data collection: Data collection was between October 2020 and February 2021 in Ota, Ogun State. The field work was in five parts: (i) documentation of FCM from online sources using smart phones; (ii) observations of how food crops were collected for medicine; (iii) informal discussions with stake holders in the FCM business; (iv) observations of preparations of 
FCM; and (v) documentation of opinions of respondents to questions posed through a questionnaire survey on FCM.

(i) Documentations from smart phones: Food crops used for preventive and curative medicines and their combinations in preparations were documented twice in a week.

(ii) Informal discussions: Discussions were held with collectors and users of FCM to validate the use of FCM among users in the Ota, Ogun State. Discussions with stakeholders were focused on the followings: curative ability to heal the sick, observed side effects when used, preparation of drugs, cautions taken during drug preparations and dosage for drugs. Others were the sources of the food crops used as medicine.

(iii) Observations: Observations also confirmed that FCM was in practice among stakeholders. Collectors of food crop parts for medicine were visited in their homesteads or in their houses to see how some of the preparations were carried out. The uses of FCM were open to observers and not restricted as in traditional medicine.

(iv) Questionnaire survey: A questionnaire interview was held among stakeholders in FCM in Ota, Ogun State. A simple random sampling was used to select respondents for a structured questionnaire interview.

(v) Structure of respondents: The respondents were 62 and made-up of the followings: food vendors 8 (13\%); mechanics 7 (11\%); carpenters 4 (6\%); traders $6(10 \%)$; university lecturers $6(10 \%)$; house builders $8(13 \%)$; house wives $8(10 \%)$; farmers $6(10 \%)$; office workers7 (11\%); and drivers $7(11 \%)$.

Analyses: Data were presented in tables and percentages; while analysis was conducted with Chi-square to provide conclusions on the hypothesis tested. The chi-square statistic was used to test the hypothesis that: food crop medicine does not reduce pressure on the forest harvest for traditional medicine in Ota, Ogun state. The chi-square $\left(\chi^{2}\right)$ is defined as: $x^{2}=\sum(\mathrm{O}-$ E) 2 / E; where $\mathrm{O}=$ Observed frequency, $\mathrm{E}=$ Expected frequency, $\sum=$ Summation and $\chi^{2}=$ Chi-Square value. The chi-square $\left(\chi^{2}\right)$ statistic is a measure of the difference between the observed and expected frequencies of the outcomes of a set of events or variables (Osemeobo, 2010a; Osemeobo, 2010b). Low calculated value of chi-square depicts that the observed data fits the expected data and the hypothesis cannot be rejected; when the chisquare value is higher than the calculated value it means that data did not fit well and the hypothesis is rejected.

\section{RESULTS}

Sources of food crop medicines: The percentages of respondents indicated the sources of FCM were from farms (20\%); gardens home gardens $(40 \%)$; homesteads $(30 \%)$ and the market $(10 \%)$. This showed that the plants were easily reached by users with little or no costs because most of the materials were collected freely.

Testing of Hypothesis: The following hypothesis was tested through likert scale method of data analysis: FCM does not reduce pressure on the forest harvest for traditional medicine in Ota, Ogun state, Nigeria. This meant that in the use of FCM, there was no significant difference in the intensity of forest harvest for traditional medicine. The question posed to derive data for analysis was based on the opinions of respondents $(\mathrm{N}=62)$ whether FCM was not reducing pressures from forest harvest for traditional medicine. The responses derived were: agree (18\%); strongly agree (62\%); disagree $(14 \%)$; and strongly disagree $(6 \%)$. The results of data were subjected to Chi-square analysis. The calculated Chi-Square with three 
degrees of freedom was 76; the P-value was 0.000. Since the p-value was less than 5\% significant level, we reject the hypothesis and accept the alternative hypothesis which states that FCM was reducing pressures on forest harvest.

Research Question: The main central research question in this study was: has food crop medicine been fully accepted in your community? Close ended responses of Yes and No were used to capture the opinions of respondents as in Table 2. A hundred percent (100\%) of the respondents claimed that FCM was in use and was finding a niche in TM which was developed and used for centuries. The opinions of the respondents were that CFCM was becoming part of the core medicine used by the people.

Table: 2 Respondents views on the use of food crop medicines

\begin{tabular}{|l|l|l|}
\hline Questions posed to respondents & $\begin{array}{l}\text { Percentages } \\
\text { Respondents } \\
\text { questions }\end{array}$ \\
& \multicolumn{1}{|c|}{$\begin{array}{c}\text { of } \\
\text { to } \\
\text { posed }\end{array}$} \\
\cline { 2 - 3 } & $\begin{array}{l}\text { Yes } \\
(\%)\end{array}$ & $\begin{array}{l}\text { No } \\
(\%)\end{array}$ \\
\hline 1. Has food crop medicine been fully accepted in your community? & 97 \\
\hline $\begin{array}{l}\text { 2. Do people use food crop medicine more than traditional medicine in your } \\
\text { community? }\end{array}$ & 81 & 19 \\
\hline 3. Do you prefer food crop medicine than traditional medicine? & 95 & 5 \\
\hline 4. Is food crop medicine cheaper than traditional medicine? & 100 & 0 \\
\hline 5. Is food crop medicine more convenient to prepare and use than traditional medicine? & 100 & 0 \\
\hline 6. Is food crop medicine food crop medicine sustainable? & 100 & 0 \\
\hline $\begin{array}{l}\text { 7. Do you think the use of food crop medicine reduces forest harvest in your } \\
\text { community? }\end{array}$ & 100 \\
\hline 8. Does food crop medicine have effects on traditional medicine? & 0 \\
\hline 9. Are there known cases of side effects in using food crop medicine? & 100 \\
\hline 10. Is food crop medicine nationally accepted? & 0 \\
\hline 11. Can food crop medicine replace traditional medicine? & 100 \\
\hline
\end{tabular}

Use of food crops in healing: The data in Table 3 presented different food crops and their medicinal values. The data were derived from online sources using smart phones and validated by respondents as correct and used by the people for curative purposes. They provided proofs that food crops have a place in human healing.

Table 3: Medicinal values of some food crops

\begin{tabular}{|l|l|}
\hline Medicinal food crops & Uses of medicinal food crops \\
\hline 1.Avocado pear (Persea americana) & $\begin{array}{l}\text { It is useful for weight loss; burning off fats; anti aging. It is a good } \\
\text { antioxidant; reduces heart diseases; suppresses cholesterol; and } \\
\text { lowers blood sugar. }\end{array}$ \\
\hline 2.Aloe vera (Aloe vera) & Improves glycolic levels and used to treat diabetes \\
\hline 2.Bitter kola (Garcinia kola) & $\begin{array}{l}\text { Used for managing the followings: malaria; diabetes; glaucoma; } \\
\text { immunity; and blood circulation. Used to cure ear problems; asthma; } \\
\text { blood pressure; prostate cancer and proper oxygenation of organs. } \\
\text { There is information that it is used to manage blocked fallopian tube } \\
\text { for conception; and food poison. It is known for treating nausea; } \\
\text { prostate cancer; infertility in men; glaucoma; and respiratory } \\
\text { diseases. It has a place in weight loss; and snake repellant. }\end{array}$ \\
\hline 3.Banana (Musa sapientum) & $\begin{array}{l}\text { Used in the management of: blood pressure regulation; stress; energy } \\
\text { boosting; hang over; insomnia; relaxation of muscles and treatment } \\
\text { of: pile, ulcers, diarrhea and cancer; diabetes; stress and depression. }\end{array}$ \\
\hline 4.Bitter leaf (Vernonia amygdalina) & $\begin{array}{l}\text { Useful in the management of: diabetes; blood pressure; weight loss; } \\
\text { fertility in women; and blood pressure. }\end{array}$ \\
\hline 5.Basil leaf (Ocium basilicum) & Improves digestion and reduces stomach cramps, It is an antioxidant \\
\hline
\end{tabular}




\begin{tabular}{|c|c|}
\hline & $\begin{array}{l}\text { and builds up white blood cells. It delays aging in skins; reduces } \\
\text { depression and manages metal health. Also, it helps to regulate } \\
\text { hormones by inducing happiness; anti stress agents. It boosts liver } \\
\text { functions; controls diabetes; lowers blood sugar; acts as skin cleanser; } \\
\text { and boosts functioning of the heart. }\end{array}$ \\
\hline 6.Cucumber (Cucumis sativus) & $\begin{array}{l}\text { Used to reduce body toxins; weight loss; treatment of eczema; and } \\
\text { arthritis. Used as anti cancer; and improves bed performance in men. } \\
\text { Used to manage belly ache; ulcer; stress and asthma. }\end{array}$ \\
\hline 7.Carrots (Daucus carota) & Improves sight, skin pigmentation and reduces wrinkles. \\
\hline 8.Coconut (Cocos nucifera) & $\begin{array}{l}\text { The water from coconut protects eyes from glaucoma and manages } \\
\text { high blood pressure. }\end{array}$ \\
\hline 9.Eewedu (jute leaf) & $\begin{array}{l}\text { used to treat constipation; eye diseases; weight loss; heart diseases; } \\
\text { and stress, Used to boost the immune system It is also used to treat } \\
\text { inflammation, wrinkles, ache; and teeth gums. Useful as anti- } \\
\text { oxidants; and for the treatment of constipation, dysentery; builds up } \\
\text { immune system; improves eye sight. }\end{array}$ \\
\hline 10.Galic (Alilium sativa) & Suppress natural hair loss and reduction in baldness \\
\hline 11.Guava Pisdium guajava) & $\begin{array}{l}\text { The fruits and leaves can reduce blood sugar level; reduces menstrual } \\
\text { pains in women; and in the treatment of cancer. }\end{array}$ \\
\hline 12.Grape fruit (Citrus paradise) & Used for managing anti aging and skin protection \\
\hline 13.Ground nut (Voandzeia subteraean & $\begin{array}{l}\text { Good for treatment for diabetes; regulates cholesterol levels; and } \\
\text { prevents cancer }\end{array}$ \\
\hline 14.Lime (Citrus aurantifolia) & $\begin{array}{l}\text { Used to manage removal of dark spots in skins; treat dandruff; and } \\
\text { helps to open skin pores }\end{array}$ \\
\hline 15.Lemon grass (Cymbopogon citrates) & $\begin{array}{l}\text { For treatment of stomach ulcer; cough; fever; and cold. It is also used } \\
\text { to regulate high blood pressure; manages exhaustion and rheumatism }\end{array}$ \\
\hline 16.Mangoe (Mangnifera indica & $\begin{array}{l}\text { It is used as antioxidant. Used to hydrate cells; moisture skins; and } \\
\text { treat diabetes. It is used to manage blood pressure reduction and } \\
\text { kidney stones }\end{array}$ \\
\hline 17.Sweet orange (Citrius aurantium) & Useful for kin improvement; and deluging pores. \\
\hline 18.Onion (Allium cepa) & $\begin{array}{l}\text { Used as antivirus and anti bacteria. Used for managing typhoid fever; } \\
\text { respiratory problems; and insomnia. }\end{array}$ \\
\hline 19.Okro (Hibiscus esculenta): & $\begin{array}{l}\text { It is useful for managing blood sugar and cholesterol. Useful as anti } \\
\text { cancer and anti fatigue in pregnant women. Used to treat stomach } \\
\text { ulcers, diabetes, and menstrual pains. Used to increase appetite; boost } \\
\text { blood pressure, manage digestive disorders and dandruff. It } \\
\text { improves sex satisfaction in men. }\end{array}$ \\
\hline 20.Pawpaw (Carica papaya) & $\begin{array}{l}\text { Useful as anti oxidants; prevents premature aging and boosts radiant } \\
\text { skins. }\end{array}$ \\
\hline 21.Effirin/ parsley (Mitracarpscus scaber) & $\begin{array}{l}\text { Used to treat stomach ache; oral infections; ease indigestion. Useful in } \\
\text { managing: cough; fever; ear ache; colon pains and urinary infections. }\end{array}$ \\
\hline 22.Tomatoe (Lycopersicum esculenta) & Commonly used as anti-aging and reduces wrinkles. \\
\hline 23.Tigernut (Cyperus esculentus) & Boost immune system, used to manage clean skin and hypertension. \\
\hline 24.Water leaf (Talinum fruticosum) & $\begin{array}{l}\text { Used to control of blood pressure; prevents blood clotting and } \\
\text { reduces risk of cataracts. It improves low light vision; reduce } \\
\text { diabetes; suppress growth of bacteria and fungi. Help to improve } \\
\text { digestion }\end{array}$ \\
\hline 25.Zobo (Hibiscus sabdariffa) & $\begin{array}{l}\text { Reduces blood sugar; flush body toxins; and manages weak erection } \\
\text { in men }\end{array}$ \\
\hline
\end{tabular}

Some special treatments of FCM: Different preparations claimed to be successful cure for ailments by respondents were presented in Table 4 . 
Table 4: Some preparations in food crop medicines

\begin{tabular}{|c|c|}
\hline Sickness & Preparations of FCM \\
\hline Malaria: & $\begin{array}{l}\text { Method A. Collect the following leaves: five mango leaves; seven guava leaves; } \\
\text { half pawpaw leaf; and ten laali leaves. Boil them in a pot of } 2 \text { littres of water for } \\
15 \text { minutes. Dosage: a tea cup (of } 145 \text { millimeters) } 3 \text { times a day. } \\
\text { Method B. Collect: } 20 \text { grams of mango tree bark; one dry male pawpaw leaf from } \\
\text { the floor; eight bitter leaves; and ten lemon grass leaves. Boil them with two } \\
\text { liters of water in a pot for } 10 \text { to } 15 \text { minutes. Dosage: a tea cup three times a day. }\end{array}$ \\
\hline 2. Dysentery & $\begin{array}{l}\text { Collect: five limes and one cucumber. Slice them and put in a container with a } \\
\text { cover. Soak them in water two liters for two days. Dosage: tea cup drink two } \\
\text { times a day for three days to flush out the system. }\end{array}$ \\
\hline Weight loss & $\begin{array}{l}\text { Method A. Collect one unripe pawpaw and slice them into two parts. Add } \\
\text { twelve leaves of laali; five leaves of mango; three leaves of guava and boil in a } \\
\text { pot of two liters of water for } 15 \text { minutes. Dosage: drink one tea cup two times a } \\
\text { day for two weeks. Do not take the third week. Repeat the fourth and fifth week } \\
\text { and stop. } \\
\text { Method B. Get two garlic bulbs, one grape, three lemons, and three bulbs of } \\
\text { ginger. Slice them and boil with } 3 \text { liters of water for fifteen minutes. Drain the } \\
\text { water from the pot. Dosage: take with a tea cup two times a day after food. } \\
\text { Repeat three times and stop. }\end{array}$ \\
\hline 4. Rheumatism & $\begin{array}{l}\text { Collect: one garlic bulb, one lemon, one ginger, ten laali leaves and one dried } \\
\text { pawpaw leaves. Boil with } 3 \text { liters of water for fifteen minutes in a covered pot. } \\
\text { Dosage: drink one tea cup twice a day. Optional: Use it to steam by covering self } \\
\text { with clothes for ten to fifteen minutes twice a day for three days. Repeat after } \\
\text { three days. }\end{array}$ \\
\hline 5.Hypertension & $\begin{array}{l}\text { Method A: Blend one overripe papaw and two bulbs of galic in half a liter of } \\
\text { water. Drink with table spoon three times a day. Repeat once and stop. Method } \\
\text { B: Collect five dried leaves of soursop and five dried leaves of avocado from the } \\
\text { floor respectively. Wash clean and process them to powder. Dosage: use for tea } \\
\text { twice a day. }\end{array}$ \\
\hline $\begin{array}{l}\text { 6. High blood sugar } \\
\text { Method }\end{array}$ & $\begin{array}{l}\text { Method A: take one unripe plantain and peel off the bark. Eat the unripe } \\
\text { plantain uncooked; and drink fluid from squeezed red jatropha. Repeat once. } \\
\text { Method B: Blend the followings: ten Ugu leaves, ten bitter leaves and ten scent } \\
\text { leaves in two liters of water. Dosage: drink with tea cup twice a day. Repeat } \\
\text { once. }\end{array}$ \\
\hline 7. Stress and depression & $\begin{array}{l}\text { Blend the followings in two and half liters of water: fifteen leaves of scent leaf, } \\
\text { twelve leaves of effirin and ten leaves of bitter leaf plant. Drink with tea cup } \\
\text { twice a day. Repeat once the following day. }\end{array}$ \\
\hline 8. Eye problems- glaucoma & $\begin{array}{l}\text { Blend the followings with two and half liters of water: five carrots, one avocado } \\
\text { pear, } 20 \text { jute leaves (ewedu), two sliced guava fruits and one sliced one onion } \\
\text { bulb. Drink with tea cup twice a day. Repeat for three days. }\end{array}$ \\
\hline 9. Stroke & $\begin{array}{l}\text { Blend twenty newly sprouted maize plus three sliced banana plus six carrots } \\
\text { plus three lime plus twelve ugu leaves in two liters of water. Sieve and drink the } \\
\text { liquid three times a day with tea cup. Repeat twice }\end{array}$ \\
\hline 10. Delayed child delivery & $\begin{array}{l}\text { Blend the following leaves in two liters of water: twenty ewedu, twenty scent } \\
\text { leaves, fifteen bitter leaves and fifteen utazi. Drink half tea cup three times a day. } \\
\text { Repeat twice. }\end{array}$ \\
\hline 11. Waist and back pains & $\begin{array}{l}\text { Method A: dry and produce powder from the following: } 15 \text { jatropha leaves, } 3 \\
\text { numbers of gingers, three pine apple leaves. Mix thoroughly in } 3 \text { liters of warm } \\
\text { water. Drink with tea cup three times a day and stop. } \\
\text { Method B. Blend twenty guava leaves in three liters of water. Drink one tea cup } \\
\text { two times a day. Repeat thrice. }\end{array}$ \\
\hline 12. Stomach ulcer & $\begin{array}{l}\text { Blend the followings: four stands of armarathtus vegetables, five black peppers, } \\
\text { and one bulb of garlic in } 3 \text { liters of warm water. Add honey when cool and mix } \\
\text { very well. Mix with pap prepared from maize and take two times a day. Repeat } \\
\text { twice. }\end{array}$ \\
\hline
\end{tabular}




\section{DISCUSSIONS}

\section{Acceptance of FCM}

The perceptions of respondents were in support of FCM. Many different reasons were advanced to various questions posed in Table 2 to support their responses. These were respectively from questions 1 to 11 as presented in Table 2 . These were: (i) majority of the people used food crop medicines which were easily derived from online sources by majority of the people at the same time; (ii) it was cheaper and easy to collect food crop medicines which were easily found around homes; (iii) items used were known, self prepared and good hygiene was maintained; (iv) materials were often collected free. Only few items were bought from the open market. (v) Home preparations were carried out with easy storage; (vi) it was sustainable as long as people plant and eat the crops used; (vii) many sellers of traditional medicine herbs from natural forests were phasing out their business due to lack of patronage; (viii) breakdown of secrecy in what people were eating and drinking to cure illness; (ix) no reports of side effects due to usage of FCM had been reported by users; (x) users of food crop medicine travelled to all places in the country and introduced them to those unaware of them. Most people in the country access the sources of food crop medicine; and (xi) Core traditional medicine was based on a combination of plants, animals and soil minerals. FCM was becoming a vital aspect of health care delivery by keeping traditional medicine alive for many centuries.

\section{Medicinal values of food crops}

Active ingredients or functional components of food are medicinal in nature (Abuaja, et. al., 2015). Therefore most the food items with high amounts of active ingredients have usefulness in reducing risks of diseases as indicated in Tables 3 and 4. Major food items such as whole grains, fruits, vegetables were known to have high concentrations of these functional components that have curative in degenerative diseases (Kumar, 2011). Clear evidences from literature have given credence to the use of FCM.

\section{Some preparations in food crop medicines}

Studies on FCM are new in the country. This was a preliminary one used to verify acceptance of FCM in Ota, Ogun state. The results of this study showed that FCM was accepted by stakeholders in Tables 3 and 4. By implication if FCM was accepted by majority of Nigerians in urban and rural areas the pressure on wild plant harvest from the forests would be reduced. Moreover, most wild medicinal plants in danger of extinction may be able to recuperate in natural forests (Osemeobo, 2010b).

It is important to put in place gathering techniques of food crop herbs in areas where FCM had been adopted at its preliminary stage to guide the people who consume them. The followings were considered useful (Pamploma-Roger, 1999): (i) plants growing in polluted places such as industries, road sides, dung hills and around chimneys should not be used for treatments; (ii) use of agrochemicals on crops for medicine should be avoided; and (iii) good plant identification is mandatory for users. Food crops are important for health care as wild plants were traditionally used for curative purposes. For example, Abuaja, et.al, (2015) proved that a functional relationship exists between components of food, health and wellbeing of people in effective treatment and prevention of diseases. Ecology of cultivated plants seemed to have been favorable for users of FCM. For example as plants of the same species always produce varied amounts and concentrations of active substances (Duke,1986) due to environmental changes and biological factors such as rainfall patterns and ages of plants (Kinghorn and Baladrin, 1993), has made dosages of FCM elastic and less harmful to users (Mowrey, 1986 ). 


\section{CONCLUSION}

The conclusion reached from this study was that FCM has the capability to reduce pressures on forest harvest for traditional medicine. As farmers and householders continue to plant CFM the hope of long time use of these for medicine would be assured and gradually divert attention from natural forests to reduce pressures on forest harvest.

\section{REFERENCES}

Abuaja, C., I.A; Ogbonna, A.C. and Osuji, C.M. (2015). Functional components and medicinal properties of food: a review, Journal of food science technology, 52 (5):25222529.

Alan, Charles Hamilton, (2004). Medicinal plants, conservation and livelihood, Journal of biodiversity and conservation 13 (8) 1477-1517

Duke, J. (1986).Handbook of medicinal herba, United States Department of Agriculture, CRC press,BocaRaton, Florida

Ezekwesili-Ofili., J., O., and Okaka, A.N.C (2019). Herbal medicines in Africa traditional medicine, Journal of Herbal Medicine (open acess).

Fatemech, J; Zahra L; Hussein, a (2018). Medicinal plants: past history and future perspective, Journal of Herbmed pharmacol 7(1):1-7

Kinghorn ,D. and Balandrin,M.(1993). Human medicinal agents from plants. Syposium series 534, Americal chemical society, Washington D c.

Kumar, S. (2011). Free radicals and antioxidants: human and food system. Advanced journal of applied scientific research: 2 (1); 129-135

Mowrey, D.B. (1986). The scientific validation of herbal medicine, Keats publishing Connecticut

Oladeji, O., (2016). The Characteristics and Roles of Medicinal Plants: Some Important Medicinal Plants in Nigeria. Natural Product Indian Journal: 12(3):102

Osemeobo, G., J., (2005a).Living on wild plants: evaluation of rural household economy in Nigeria, Environmental Practice: 7:246-256

Osemeobo, G., J., (2005b).Living on forests: women and household security in Nigeria, Small-scale forest economics, management and Policy: 4 (3): 343-358.

Osemeobo, G., J., (2010a). Impact of traditional practices on medicinal plant trade in the rainforest of Nigeria, Journal of Geography, environment and sustainability, 3 (3) 56-66

Osemeobo, G., J., (2010b). Can the rainforest of Nigeria sustain trade in medicinal plants? Journal of social forestry 3(1) 66-80

Osemeobo, G., J., (2011). Impact of fiscal policy failures on sustainable forest management in Nigeria, Spanish Journal of rural development: 11 (3):13 -20

Osemeobo, G., J., (2018). Loss of ecological knowledge: impacts on people and ecosystem conservation, Journal of Applied Sciences and Environment, 1: (2) 14-22

Pamplona-Roger, G., D., (1999). Encyclopedia of medicinal plants Vol.1, Education and health Library, Madrid, Spain, 398pp

Pandey, A., K., and Sativa, S., (2012). Harvesting and post harvest processing of medicinal plants: problems and prospects, The Pharm Innovation Journal, 6 (12) 229-235

Peter, S., (2020). Conservation strategies for medicinal and aromatic plants, in IPGRI report of a working and aromatic plants: first meeting 12-14 Semptember 2020, Gozd Martu, Siovenia. 
Suellen, L., S., Agwai, I., Ojengbede, O., (2020). Traditional medicine usage among adult women in Ibadan, Nigeria: across-sectional study, BMC complementary Medicine and Therapies, 20:93

World Health Organization, (2019). Enhancing the role of traditional medicine in health systems: a strategy for the African region: 63rd Session of the Regional Committee for Africa. WHO Regional Office for Africa, $227 \mathrm{Pp}$. 